NBER WORKING PAPER SERIES

\title{
AGENCY CONFLICTS, ASSET SUBSTITUTION, AND SECURITIZATION
}

\author{
Yingjin Hila Gan \\ Christopher Mayer
}

Working Paper 12359

http://www.nber.org/papers/w12359

\author{
NATIONAL BUREAU OF ECONOMIC RESEARCH \\ 1050 Massachusetts Avenue \\ Cambridge, MA 02138 \\ July 2006
}

The authors would like to thank Steve Drucker, Larry Glosten, Joe Gyourko, Charles Jones, Brigitte Madrian, Matt Rhodes-Kropf, Neng Wang, Matt White, Joel Waldfogel, and seminar participants at Harvard Business School, NYU Stern School, the Wharton School of the University of Pennsylvania, and Columbia Business School for helpful comments. We are especially grateful to Trepp for providing critical data used in this paper. The Paul Milstein Center for Real Estate at Columbia Business School provided financial support for this research. The views expressed herein are those of the author(s) and do not necessarily reflect the views of the National Bureau of Economic Research.

(C2006 by Yingjin Hila Gan and Christopher Mayer. All rights reserved. Short sections of text, not to exceed two paragraphs, may be quoted without explicit permission provided that full credit, including $\odot$ notice, is given to the source. 
Agency Conflicts, Asset Substitution, and Securitization

Yingjin Hila Gan and Christopher Mayer

NBER Working Paper No. 12359

July 2006

JEL No. D8, G2, G3, L2

\begin{abstract}
Asset-backed securities represent one of the largest and fastest growing financial markets. Under securitization, agents perform functions (for fees) that would alternatively be performed by a vertically integrated lender with ownership of a whole loan. We examine how outsourcing impacts performance using data on 357 commercial mortgage-backed securities deals with over 46,000 individual loans. To alleviate agency conflicts in managing troubled loans, underwriters often sell the first-loss position to the special servicer, the party who is charged with handling delinquencies and defaults. When holding the first-loss position, special servicers appear to behave more efficiently, making fewer costly transfers of delinquent loans to special servicing, but liquidating a higher percentage of loans that are referred to special servicing. Special servicers are also more likely to own the first loss position in deals that require additional effort (deals with higher delinquencies). Market pricing reflects the existence of agency costs. Despite the apparent reduction of agency costs, the first-loss position is increasingly owned by a party other than the special servicer. We pose a number of explanations, including conflicts between junior and senior securities holders (the asset substitution problem) and risk aversion among special servicers. Consistent with asset substitution, we show that special servicers delay liquidation when they hold the first-loss position in deals with more severe delinquency problems.
\end{abstract}

Christopher J. Mayer

Columbia Business School

3022 Broadway, Uris Hall \#808

New York, NY 10025

and NBER

cm310@columbia.edu

Yingjin Hila Gan

Lehman Brothers Inc.

745 Seventh Ave. 15th Floor

New York, NY 10019

yingjin.gan@lehman.com 
Asset-backed securities are one of the most important financial innovations in recent decades. According to the Federal Reserve, as of the end of 2005, the value of outstanding of mortgageand other asset-backed securities was $\$ 6.7$ trillion, about $\$ 1.7$ trillion larger than outstanding amount of non-ABS corporate bonds. About one-half of mortgages, one-third of trade receivables, and one-fourth of consumer credit are securitized in the US. ${ }^{1}$ The asset-backed securities (ABS) market has developed along many dimensions. Once dominated by residential mortgages, this market now includes securities backed by loans on cars, manufactured homes, credit cards, trade receivables, commercial real estate, leases, franchise debt, student loans, and even securities from previous securitizations (CDOs).

In a typical securitization, a large numbers of assets are grouped together in a single pool.

Claims to the cash flows from the pooled loans are sold as securities, where the economic claims to cash flows are divided (or "tranched") based on a strict priority system. Parties pay a premium to buy the most senior tranches, whose capital is protected by the existence of more junior securities that absorb initial losses. This structure is similar to that of dividing up claims to a firm's cash flows between equity holders, junior creditors, and senior creditors. Equity holders are paid only after the claims of all the creditors are satisfied. If the firm's assets do not generate enough cash flow to pay-off its debt, the equity position is wiped out. Similarly, senior creditors are paid in full before junior creditors receive any cash flow. Some securitizations may have as many as twenty separate tranches in their capital structure.

The growth of ABS has resulted from a series of economic, legal, and regulatory developments. ABS are publicly-traded and rated by independent rating agencies, resulting in the generation of

\footnotetext{
${ }^{1}$ Flow of Fund Tables L1, L4, L125, L126, L212, for 4Q, 2005, Federal Reserve Board, released March 9, 2006.
} 
a great deal of public information about the performance and valuation of the underlying assets and the traded securities. Regulators give insurance companies highly preferential capital treatment when they hold investment grade ABS instead of less transparent whole loans. ${ }^{2}$ The legal system also provides relatively strict protection for the cash flow priorities inherent in the bankruptcy-remote entities that are a fundamental part of securitization. ${ }^{3}$ In addition, the creation of a wide variety of claims to debt securities has helped to complete capital markets, allowing investors to purchase positions all along the risk/return frontier. ${ }^{4}$ Specialized parties have emerged to perform many functions that were previously performed by vertically integrated lenders, possibly allowing for increased efficiency and specialization. Finally, ABS are typically more liquid than whole loans.

Yet securitization also creates important (and previously unexplored) organizational costs associated with the separation of ownership and control of assets and the parsing of equity interests into a large number of relatively thin ownership tranches. Traditionally, a bank or an insurance company would own and manage all of the loans it originated, collecting payments and making all decisions in the event of delinquency and default. ${ }^{5}$ With securitization, a thirdparty (the special servicer) takes over responsibility for managing troubled loans. Special servicers usually receive a fixed fee for monitoring the entire pool of loans, plus a percentage of the outstanding balance of any loans that are in special servicing. These fees are paid before investors receive the proceeds from a workout or foreclosure of a troubled loan.

\footnotetext{
${ }^{2}$ See Kopcke (1996), for example. Previous papers reject the hypothesis that securitization has grown purely due to regulatory arbitrage in residential mortgages (Ambrose et. al. 2006) and credit cards (Calomiris and Mason 2004).

${ }^{3}$ Ayotte and Gaon (2005) point out that strict payout rules are obscured in bankruptcy, but that the bankruptcy remote structure used in ABS typically ensures that the strict prioritization of cash flows holds for financial firms. ${ }^{4}$ Gaur, et., al, (2003) for a further discussion of pricing securities in incomplete markets.

${ }^{5}$ For larger loans, a lender might syndicate a portion of a loan to multiple parties, but retain control of servicing. Of course, problems might still arise when originators sell loans to less-informed parties. (See Ciochetti, et. al. 2003)
} 
Of course, fee-based special servicers may not always behave in the best interest of the investors. To better align the interests of the special servicers and investors, special servicers sometimes hold the first loss position (the so-called the "B-piece”), which is the residual claimant in a securitization. The procedure of having the special servicer own the first loss position is intended to ensure that the special servicer exerts optimal effort in maximizing the value of the collateral. The fees and losses attributable to the most problematic loans as well as the benefits from effective loan management come from the pockets of the B-piece holder.

Yet such arrangements create a new set of conflicts. First, special servicers may be risk averse and require additional compensation for bearing the risk of holding the first-loss position in every deal. ${ }^{6}$ In addition, special servicers face the classic asset substitution problem associated with equity holders in highly leveraged firms. The first-loss position often represents three percent or less of the entire ABS capital structure. When an increasing number of loans in a securitization face potential losses, special servicers have an incentive to extend loans or take other risks as the value of their equity position falls. This is analogous to the decisions made by savings and loan executives to extend loans when large losses on real estate loans impaired their capital in the late 1980s.

Yet, with less than three percent ownership in a deal, special servicers often have the equivalent of less capital than S\&Ls held prior to the downturn of the late 1980s. Some commentators have expressed concern with the rapid growth in ABS and the lack of previous experience with a large number of defaults. They have worried that the ABS structure might perform less efficiently

\footnotetext{
${ }^{6}$ Typically, special servicers must maintain an investment grade rating or face possible removal. Such a rating requires a lot of costly capital when holding a concentrated loss position across many deals, especially as it is virtually impossible to hedge these securities.
} 
than banks in handling troubled loans, potentially slowing the recovery of the economy from a recession.

We examine the performance of securitizations utilizing data on 357 commercial mortgagebacked securities (CMBS) deals with over 46,000 individual loans. Previous papers examine default and prepayment decisions without accounting for these conflicts of interest. ${ }^{7}$

We demonstrate the existence of appreciable principal-agent conflicts in the securitization process. Special servicers appear to put additional effort into identifying and efficiently managing the most troubled loans when they own the first-loss position. Special servicers are up to 14 percent less likely to transfer a delinquent loan to special servicing in deals where they hold the B-piece. Conditional on special servicing, special servicers are five percent more likely to foreclose and liquidate a loan when they own the B-piece. These results hold when we include fixed effects for individual special servicers, suggesting that special servicers have a different evaluation process for deals based on whether they own the first loss position. ${ }^{8}$ We also address the possibility that experienced special servicers might choose to hold the B-piece only in deals with high quality loans. In fact, the opposite is the case. Deals in which the special servicer owns the B-piece experience worse delinquency and default behavior, conditional on observable loan characteristics. These findings suggest that CMBS underwriters are well-informed about ex-ante loan quality and use high-powered incentives when the marginal returns to incentive alignment are strongest.

\footnotetext{
${ }^{7}$ See Ambrose and Sanders (2003), Chen and Deng (2003), and Deng et. al (2004). Other work examines loan default, or subordination levels (Downing and Wallace 2005).

${ }^{8}$ One industry participant conceded to the authors that some servicers used the "A" team on deals in which they owned the first-loss position, but the "B" team on deals in which they received only fees.
} 
Evidence from initial bond prices for CMBS securities also supports our agency cost interpretation. Prices are higher (yields are lower) for junior securities in deals in which the special servicer owns the first-loss position, even though these deals have worse delinquency experiences. Junior securities are the most likely to be positively impacted by superior performance of the special servicer. Spreads on the most senior (investment-grade) securities appear unaffected by the ownership of the B-piece, which is consistent with the view that such securities are rarely impacted by losses from defaults.

Despite the seemingly important alignment of interests, the special servicer does not own the Bpiece in more than one-third of all CMBS securitizations in our data, a percentage that has grown over time. We suggest two possible reasons. Risk aversion among special servicers may play a role. Special servicers own the B-piece in a smaller percentage of deals when total issuance of CMBS securities is highest. We also find evidence of conflicts of interest between equity holders and creditors (asset substitution). In deals with higher delinquencies, special servicers who own the B-piece appear to slow the foreclosure process for loans in special servicing. This pattern suggests that special servicers may be susceptible to the same kinds of problems that characterized undercapitalized banks when losses rose.

\section{Theory and predictions}

Securitization accentuates agency conflicts resulting from the separation of ownership and control of assets. The discussion of managerial incentive problems dates back as far back as Adam Smith’s “The Wealth of Nations.” Articles such as Jensen and Meckling (1976), Harris and Raviv (1978), and Fama and Jensen (1983) suggest that, even with elaborate (and costly) 
contracts between managers and shareholders. Other market mechanisms such as the threat of takeover and "ex-post settling up” do not fully discipline managers (Fama 1980). Laffont and Martimort (2002) discuss these issues extensively.

Information asymmetries are a second important factor impacting the benefits of securitization and the liquidity of loans as an alternative vehicle for hedging risk. Gorton and Pennacchi (1995) show that contract mechanisms such as implicit guarantees or partial sales of loans can mitigate moral hazard problems in which lenders do not exert enough effort investigating the risk associated with loans that they intend to sell. In a similar vein, DeMarzo (2005) argues that securitization allows sophisticated intermediaries with special skills in valuing assets to mitigate the "lemons" problem when selling assets to the market. However, for many securitizations, including the CMBS we examine in this paper, these mechanisms do not appear to operate. Originators and underwriters almost never hold the risks from loan failures once securities have been issued, possibly due to regulatory capital rules. ${ }^{9}$ Neither paper examines the incentive misalignment between investors and managers once securitizations are created.

In the face of unobservable effort by managers and asymmetric information about the firm's prospects, shareholders cannot obtain the first-best outcome for the firm. Similar problems exist in most securitizations. While junior security holders (who are equivalent to equity holders in a corporation) have the right to choose and change the special servicer, they often lack the ability to monitor managerial effort and deal quality. In the face of principal-agent conflicts, highpowered (outcome-based) compensation can often provide better incentives for the agent (Eisenhardt 1989). However, if agents are more risk averse than the principals and their actions

\footnotetext{
${ }^{9}$ Often, the servicer can require the originator and/or the underwriter to repurchase loans in the case of material misrepresentations of loan information. However, this is a very strict standard that is rarely used.
} 
are not observable and verifiable, such high-powered compensation will not obtain the first-best outcome (Shavell, 1979).

Special servicers may well be more risk averse than other potential investors in low-rated CMBS tranches and have a lower willingness to pay than outside investors for the B-piece. Special servicers in CMBS face a heavy exposure to commercial real estate markets that is difficult to diversify. The B-piece usually represents about three percent or less of the capital in CMBS deals, but bears all of the losses from any loans in the securitization. The top 10 special servicers cover more than $80 \%$ of the CMBS market, which totals hundreds of billions of dollars of outstanding loan balances. While CMBS special servicers are experts in assessing and managing troubled commercial real estate loans, this expertise may not extend to other types of assets. Holding a highly concentrated loss position in every CMBS deal creates the potential for large losses in the event of a real estate downturn. Even worse, new transactions volume in a real estate downturn would likely fall, further harming near-term profits and cash-flow. Finally, rating agencies require all servicers to have an above-investment-grade rating in order to perform their function, so special servicers must hold a large amount of (costly) capital if they hold the Bpiece on every deal. Other potential purchasers of low-rated CMBS securities do not face similar capital requirements and can better diversify themselves from exposure to commercial real estate.

The usual CMBS securitization is created by an underwriter that chooses the management structure (in conjunction with the rating agencies) and markets the securities to investors. Underwriters, usually large banks, want to maximize the profits from each securitization, but also want to maintain their reputation for future securitizations. Underwriters may have additional information about loans than investors and the rating agencies, especially since underwriters originate many of the loans in their portfolios. Thus, an underwriter trades-off 
possibly lower revenue associated with the special servicer purchasing the B-piece against the benefits of better-aligned incentives when the special servicer owns the B-piece. The underwriter should sell the B-piece to the special servicer in circumstances when the incremental benefit from a high-powered incentive scheme is especially large.

The optimal (second-best) compensation scheme employs higher-powered incentive schemes when: 1) an agent's effort has a larger effect on profits, 2) when asymmetric information problems make effort more difficult to observe by outsiders, 3) and when agents are less riskaverse. Conditions 1 and 2 naturally lead to our first hypothesis:

H1: The special servicer is more likely to hold the B-piece in deals with (1) a higher expected delinquency rate and (2) greater asymmetric information.

High-powered incentive schemes are more valuable in deals that require greater effort by the agents; i.e., in deals with loans that have a higher expected delinquency. A loan delinquency occurs when the borrower is late in making payments or violates one or more terms of the initial loan agreement. Delinquencies are usually unrelated to actions by lenders or servicers. However, effort by the lender or special servicer becomes much more important in handling loans once they become delinquent. Thus it becomes more important to align incentives between the principal and the agent in deals with greater potential delinquencies.

Of course, not all delinquencies are equal. Agency theory shows that information curbs agent opportunism. (Fama 1980 and Fama and Jensen 1983). Thus the outcome-based compensation is more attractive when the asymmetric information is greater. We proxy for asymmetric information using the extent to which deals differ in realized delinquency rates after controlling for observable variables. Investors are able to assess the risks associated with well-known 
quality indicators such as the loan to value ratio (LTV) and the debt service coverage ratio (DSCR). However, when a seemingly high-quality loan (low LTV and high DSCR) gets into trouble, investors may have a harder time understanding and predicting the loss recovery. Underwriters should be more likely to sell the first-loss position to the special servicer when private information about the likelihood of delinquency suggests that a deal will have a higher delinquency rate.

Of course, it is important to examine whether having the special servicer hold the first-loss position is effective in alleviating agency problems as theory predicts. Ideally, we would examine the effectiveness of aligning interests by measuring whether investors obtain smaller losses when the special servicer owns the B-piece. Unfortunately, we do not observe actual losses. Instead we have data on whether a loan is transferred into special servicing and, conditional on special servicing, whether or not a loan is liquidated (either thru foreclosure or the special servicer acquiring ownership of the real estate). We also observe initial prices of securities for a small portion of the CMBS deals in our sample, allowing us to see how the market values different deal structures. The combination of these variables allows us to examine the efficiency of the special servicer's actions even without data on monetary losses from default.

We begin with the first stage of the loan management process:

H2: Controlling for loan quality, fewer loans will be transferred into costly special servicing when the special servicer holds the B-piece.

As an agent, the special servicer is conflicted. She receives fees based on the number and dollar value of loans that are in special servicing, creating an incentive to transfer more loans into special servicing than is optimal from the perspective of the investors. In addition, the agent 
must exert costly effort to determine which loans have severe enough problems to justify the additional cost and attention. Recognizing this conflict, most securitizations have a master servicer who oversees each deal. The master servicer, whose primary function is to monitor the timely collection and distribution of principal and interest, must agree with any proposed loan transfers into special servicing. Nonetheless, the special servicer has discretion in deciding whether and when to transfer the delinquent loans. Neither investors nor the master servicer are sufficiently well-informed to fully discipline the special servicer.

If the special servicer owns the first-loss position, she is the residual claimant and thus pays all costs associated with transferring loans into special servicing. In this circumstance, the special servicer will choose the first-best solution. Thus the special servicer should transfer fewer delinquent loans into special servicing when she owns the B-piece. When the special servicer does not own the first-loss position, she has incentives to shirk in investigating potentially troubled loans and to transfer "too many" loans into costly special servicing to earn higher fees. In fact, Fitch, a major rating agency, expressed concern that some special servicers in the commercial mortgage securities market unnecessarily transfer assets into special servicing (Mortgage Banker Association 10/2/2003).

Next, we consider the work-out stage when loans are in special servicing. Special servicers have wide discretion on how they handle a troubled loan. Their options include doing nothing, extending the payment period, waiving loan terms, restructuring the loan, possibly forgiving some portion of the principal amount, and ultimately foreclosing on the loan and liquidating the underlying collateral. Here we point out that the efficiency of the special servicer's actions depends critically on the size of potential losses in a given CMBS deal. Thus securitzation does 
not align interests as would occur if a single lender owned all of the loans in a securitization and made all foreclosure decisions.

H3A: When potential losses are relatively small, the special servicer will liquidate loans in special servicing more quickly when holding the B-piece.

When the special servicer acts as the agent (as opposed to being the principal when she owns the B-piece), we would expect that she will liquidate fewer loans than is optimal for the investors. Foreclosure is lengthy and involves costly effort for the special servicer, including intensive research in looking for potential buyers, negotiations with sophisticated players, and expensive legal procedures. Ciochetti and Riddiough (1998) report that the average elapsed time from the beginning of the foreclosure process to the date at which title to the property is obtained by the investor (or is sold by the courthouse) is approximately 9 months. By postponing this decision, the special servicer receives two benefits: she collects additional fees associated with a loan spending more time in special servicing and 2) there is some chance that the loan will become current without the special servicer exerting any effort. In the same report mentioned above, Fitch expressed concern that some special servicers use “excessive litigation” to retrieve unpaid borrower funds, effectively extending the special servicing period. However, if the loan does not become current and has to be liquidated later, the recovery rate in present value terms may be lower because owners of severely distressed real estate are likely to take additional risks and to postpone necessary capital improvements and renovations. Therefore, under these conditions, the special servicer who does not own the B-piece will be slower to liquidate than is optimal for investors and than a single lender would. Of course, when the special servicer owns the B-piece, she pays all of the costs in special servicing out of her own pocket and should make first-best decisions. 
H3B: When potential losses are large, a special servicer who owns the B-piece has an additional incentive to delay liquidation.

As potential losses in a given securitization grow, the special servicer faces conflicting incentives. At some point, total losses would exceed the value of the B-piece. As such, when the special servicer owns the B-piece and potential losses are large enough, the special servicer might optimally choose to extend troubled loans rather than foreclosing and ensuring that the losses eliminate the value associated with the B-piece. (Riddiough 1997) This is the well-known asset substitution problem. The incentive to extend loans grows with the size of potential losses for the B-piece. A special servicer who does not own the first-loss position faces no such additional incentives to extend loans and thus may actually foreclose more quickly than a special servicer who owned the B-piece if the deal faces large enough possible losses.

Finally, we use data on securities prices to measure the effect of incentive alignment on the anticipated efficiency of the special servicer's actions. Securities prices should reflect the benefits of incentive alignment.

H4: Securities based on deals in which the special servicer owns the B-piece should sell at higher prices. The price effects should be most pronounced for the lowest rated tranches that are most likely to suffer losses if the special servicer does not perform efficiently.

All else equal, if having the special servicer own the B-piece aligns incentives, as we argue above, we should expect securities prices to reflect these benefits. Thus prices should be highest for securities in which the special servicer owns the first-loss position. 
Of course we should be concerned that we are unable to perfectly observe loan quality and prices might reflect factors such as loan quality or deal structure in addition to incentive alignment. We take several steps to address this problem. First, we examine prices (yields) within a given rating class. Rating agencies are quite concerned about the quality of loans in a pool and their ratings directly reflect the impact of loan quality on defaults and losses. Yet rating agencies do not know whether or not the special servicer will eventually own the B-piece (ratings are determined at an earlier time period), even as investors know this information when a deal is taken to market. Thus investors should be willing to pay a premium for securities of a given ratings class in a deal if they think that the special servicer will perform more efficiently relative to another deal in which she does not own the B-piece.

Second, we examine prices within each ratings class. If deals in which the special servicer owns the first-loss position are more attractive for reasons that are unrelated to losses (say these deals have better marketing or a superior underwriter), we would expect that prices of all securities in these deals would be higher. Instead, if the reason for differential pricing is optimal effort by the special servicer in dealing with delinquencies and defaults, prices of lowest-rated securities-those with the greatest likelihood of suffering losses due to defaults--should be most impacted by whether the special servicer owns the B-piece.

We address the question of adverse selection in deal quality by examining the ultimate default behavior of loans. We do not directly observe ex-ante loan quality. An alternative hypothesis that might be a concern is that special servicers use their superior knowledge of loan quality such that they only choose to purchase the B-piece in deals in which their private information says that loans are above-average quality. Fortunately, such an alternative hypothesis is testable in the data. If adverse selection were an important feature of this market, we would expect that, 
conditional on observable data, deals in which the special servicer owns the B-piece would have better-than-average delinquency and default experience. We reject this hypothesis in the data that follows.

\section{Data}

The data for this study comes from two main sources: Trepp Data Feed and Commercial Mortgage Alert (CMA) CMBS Data. Trepp is the leading data provider in commercial mortgage-backed securities and is used by most major investors in the CMBS market. Trepp Data Feed consists of four separate files: a property file, a loan file, a deal file, and a bond file. Each file includes annual, end-of-year performance data, including cash flow, for all properties, loans, deals, and bonds. We obtain a number of important variables from Trepp, including loan delinquency status, the date on which a loan was transferred to the special servicer, the date on which a loan was returned back to the master servicer, the date on which a loan was foreclosed or transferred to REO (Real Estate Owned by the special servicer), the loan-to-value ratio (LTV), and debt service coverage ratio (DSCR). The DSCR is the ratio of property cash flow to total debt payments. Thus a ratio of 1.25 implies that property cash flow is $1.25 \mathrm{x}$ required debt service payments, or that property cash flow could fall by $20 \%$ and still allow the debtor to cover his loan payments from existing cash flow.

CMA is a weekly newsletter. It provides historical data on all new CMBS issuances and the initial prices of many bonds sold to investors at the time of the securitization. CMA lists the owner's name for many junior pieces ${ }^{10}$, enabling us to identify the most important variable in our analysis: whether the special servicer (SPS) owns the B-piece. Initial bond prices include the

\footnotetext{
${ }^{10}$ There is no such as data field "B-piece buyer" in the data base itself. However, there is a short paragraph note for each deal and in many deals the B-piece buyer's name is listed. We add this field by going over all the notes.
} 
yield and spread over benchmark for all tranches that are publicly placed at the time of the initial securitization. Unfortunately, we are unable to obtain consistent pricing information for securities once the initial sale of securities takes place.

The Trepp data consists of an unbalanced panel of 839 deals with up to six years of observations (1998-2003), depending on when the deal was originated. We merge the files from Trepp and CMA by issuer name and serial number, successfully matching 702 of the 839 deals. Of these 702 deals, 588 have the name of the special servicer and 360 have B-piece ownership. Overall, our final sample has 357 deals (with 46,492 loans) that have both the B-piece ownership and special servicer information. Table 1 lists these deals by the year that the deal closed. In recent years, the average deal size has varied between $\$ 786$ million and \$1,164 million, while the average number of loans per deal ranges from 105 to 232. Total CMBS issuance peaked in 1998 and again in 2003 at the end of our sample.

Table 2 summarizes the percentage of deals that the special servicer owns the B-piece for all fifteen special servicers that service at least 5 deals in our sample. These special servicers manage deals that account for $89 \%$ of the number of deals and $92 \%$ of the loan balances in our sample, suggesting that the special servicing industry is moderately concentrated. Among the 317 deals that these special servicers manage, the special servicer owns the B-piece in 203 (64\%) deals. Although most special servicers own the B-piece in at least some portion of their deals, some special servicers show a strong "preference" for one type of structure or the other. This fact is especially true for the top 6 special servicers. We include special servicer dummies in all default and delinquency specifications to control for possible differences in preferences or expertise across special servicers. 


\section{Results}

\section{A. When do special servicers hold the B-piece? (Hypothesis H1)}

We begin by comparing the characteristics of deals based on whether or not the special servicer holds the B-piece (Table 3). The results are clearly consistent with our first hypothesis, H1. Exante observable characteristics do not vary economically or statistically in deals based on whether the special servicer holds the B-piece. We examine the most commonly used measures of deal size or performance: loan balances, number of loans, LTV, DSCR, Weighted Average Coupon (WAC), and AAA subordination (percentage of the deal that is rated AAA by the rating agencies).

Yet, ex-poste, the deals in which the special servicer owns the low-rated tranche have appreciably higher delinquency rates. For delinquencies of greater than 30 days, these differences are statistically significant at the $5 \%$ level. Note that delinquency is a relatively objective measure of a troubled loan, with delinquencies typically being triggered by late payments or in some cases, cash flow falling to very low levels. Effort by the special servicer should have little effect on a loan becoming delinquent. This evidence also suggests that special servicers do not have superior information relative to the underwriter that allows them to “cherry-pick” (purchase) the B-piece in only the best (unobserved) quality deals.

Of course, these are just unconditional means. To systematically explore this point, we examine the likelihood of delinquency in a deal in year t conditional on observable information in year t-1. The results are presented in Table 4. The dependent variable is the delinquency rate for each deal; that is, the ratio of the outstanding balance of loans in delinquency to the total outstanding of balances for the deal. Explanatory variables include measures of observable quality (LTV, 
DSCR, controls for different property types), year dummy variables, and whether the special servicer (SPS) owns the B-piece.

In all specifications, the coefficient on the dummy variable indicating that the special servicer owns the B-piece is positive and statistically significant at conventional confidence levels, implying that special servicers hold the B-piece in lower quality deals, after controlling for observable characteristics. Investors almost surely have a difficult time monitoring delinquencies that are uncorrelated with observable measures of quality such as DSCR and LTV.

Other coefficients in the regression are either insignificant or have the expected sign. The lack of importance of LTV in predicting delinquency is not surprising given that originators and underwriters have more information than these characteristics and should be expected to use this information when deciding which loans to include in a pool. ${ }^{11}$ High LTV loans in the pool may have other hard-to-measure attributes indicating that such loans face a lower delinquency or default rate. (e.g., the property that serves as collateral for a high LTV loan may have a longterm lease with a credit-quality tenant.) The simultaneity of many loan and pool characteristics just highlights the importance of unobserved quality in this market and thus the important role of servicers in managing loan delinquencies and defaults.

Other columns provide additional controls to ensure that our results are not driven by functional form. To account for the strong non-linearity in the effects of LTV and DSCR, we use dummy variables instead of the numerical values in columns 2,4 , and 6 . In the first two columns, we

\footnotetext{
${ }^{11}$ Archer, Elmer, Harrison and Ling (2002) argue for the endogeneity in commercial mortgage underwriting in terms of LTV ratio, which would imply no empirical relationship between default and LTV because lender would require lower LTVs for high risk mortgages. They examine 495 multifamily mortgages securitized by the Resolution Trust Corporation (RTC) and the Federal Deposit Insurance Corporation (FDIC) and find no evidence of LTV effect on default.
} 
include only a sparse set of covariates, including whether the special servicer owns the B-piece, LTV, and DSCR. Columns 3 and 4 add year dummies and property type controls.

Most strikingly, the last two columns include dummy variables for each special servicer and thus rely on variation in deals for individual special servicers based on whether or not they own the B-piece. Despite the potential loss of variation, the coefficient on whether the special servicer owns the B-piece rises in magnitude.

The results in this sub-section are consistent with hypothesis H1. Deals in which the special servicer holds the B-piece are more likely to be delinquent, but do not differ on observable characteristics. This finding is consistent with our expectation that an underwriter who has superior information on the true quality of deals will choose to align incentives through having the special servicer own the B-piece in deals with a higher expected delinquency rate.

\section{B. Agency conflicts in transferring loans to special servicing (H2)}

Next, we investigate whether holding the B-piece mitigates agency problems by examining when the special servicer transfers loans to special servicing. Special servicing is costly. Hypothesis H2 predicts that the special servicer will be less likely to transfer a delinquent loan to special servicing when she owns the B-piece for two reasons: first, she exerts more effort in identifying the right loans to transfer; and second, the special servicer is the residual claimant and thus she does not benefit from additional fees paid while loans are in special servicing. Table 5 reports the results of a probit model in which the dependent variable equals one when a delinquent loan is transferred to special servicing within certain period of time. Independent variables are whether the special servicer owns the B-piece and other explanatory variables. We examine transfers of delinquent loans that occur between two and six months after delinquency. 
The estimated coefficients on the dummy variable indicating that the special servicer owns the B-piece are negative and highly significantly different from zero. The coefficients are large, suggesting a 7.5 to 13.8 percent lower likelihood of transferring loans into special servicing when the special servicer owns the most junior tranche. As the time period for action gets longer and special servicers have time to investigate troubled loans, the coefficient on special servicer owning the B-piece grows in magnitude. Industry analysts suggest that low cash flow (low debt service coverage ratio) is the most troubling indicator of eventual default so, not surprisingly, low DSCR loans are more likely to be transferred into special servicing. The negative coefficient on high LTV loans is a bit surprising. For seasoned loans, however, true property value is usually hard to measure, unlike cash flow. These findings confirm our prediction that the alignment of interests helps to alleviate the agency problem at the transfer stage.

\section{Agency conflicts in working out troubled loans (H3A and H3B)}

Once a loan reaches the special servicing stage, the special servicer must now exert additional effort to quickly and accurately decide how to manage the troubled loans. Her choices include: 1) acquiring the property from the borrower through the foreclosure or bankruptcy process and liquidating the asset or 2) negotiating with the existing borrower, possibly extending the loan, lowering the interest rate, and/or writing down a portion of the loan principal. As discussed in Section II, we expect that the alignment of interests will cause the special servicer to liquidate sooner under ordinary circumstances (Hypothesis H3A). Delaying action allows the special servicer to avoid exerting costly effort in identifying loans that are good candidates for liquidation as well as earn additional fees when loans spend a longer time in special servicing. In addition, a longer liquidation process is often costly for loan investors because collateral values can decline rapidly over time, as property owners typically cut back on maintenance and take 
additional risk on highly-leveraged properties. When the special servicer is the residual claimant as owner of the B-piece, she internalizes these costs and has incentives to act more quickly. However, as a larger percentage of the loans in a deal get in trouble, the likelihood grows that potential losses will exceed the size of the junior piece. At that point, having the special servicer own the B-piece creates conflicts between the junior and senior securities holders. As potential losses grow, a special servicer who also holds the junior piece may choose to delay liquidation in the hope that property cash flow or values will rise (Hypothesis H3B).

In Table 6, we run a probit regression estimating the likelihood that a loan is liquidated within a fixed period of time--6 months or a year. We define a property as being liquidated if the records indicate a foreclosure, a REO transaction, or a bankruptcy. As in other regressions, we control for other observable quality variables, including LTV, DSCR, deal type dummies, property type dummies, dummy variables for origination year, and special servicer dummies. As predicted, loans in deals in which the special servicer owns the B-piece are between three and five percent more likely to be liquidated within six months or a year, a result that is statistically significant with at least 90 percent confidence in all specifications. As before, the magnitude of the coefficients rises when we include special servicer dummy variables, although the standard error increases as well. These results suggest that a given special servicer behaves differently depending on whether she owns the B-piece, a strong indication that agency conflicts are important in this market.

The coefficients on other controls are consistent with expectations. LTV has a positive coefficient, consistent with previous literature. Specifications using dummy variables for LTV instead of the continuous value show that the main impact of LTV is for loans with an LTV 
higher than $80 \%$. The coefficients on DSCR have the expected negative sign, although they are significant only in columns 4 to 6 .

Next we examine whether the special servicer's actions change when the percentage of seriously delinquent loans rises in a pool. We define the extent to which a deal faces serious delinquency based on whether the sum of all delinquent loan balances in a deal exceeds various thresholds. We include the measure of serious delinquency in the regression directly, as well as including an interaction term between this dummy variable and whether the special servicer owns the B-piece. We expect the interaction term to be negative if conflicts between securities holders are material in seriously delinquent deals.

Table 7 presents evidence of conflicts between senior and junior tranches when a deal gets into serious trouble (H3B). The coefficient on the interaction term denoting that a deal has serious delinquencies and the special servicer owns the most junior tranche is negative and statistically different from zero with at least 93 percent confidence in all specifications. The coefficient on whether the special servicer owns the B-piece is positive and statistically significant. Putting these two coefficients together suggests that special servicers who own the first-loss position act differently when aggregate potential losses rise. For deals with a relatively small percentage delinquent loans, the special servicer liquidates more quickly when she owns the most junior tranche. Yet when the percentage of delinquencies rises, the special servicer appears to delay liquidation. The coefficient on the dummy for serious delinquency is also positive and significant in most columns, suggesting either that the special servicer becomes more aggressive when many loans in a deal are in serious trouble, possibly due to concern with reputation, or that unobserved quality is worse when many loans in a deal get in trouble. 


\section{Unobserved quality for deals in which the special servicer owns the B-piece}

Lower transfer rates into special servicing and higher liquidation rates once in special servicing for deals with small potential losses in which the special servicer owns the B-piece are consistent with the hypothesis that the special servicer exerts more effort in identifying the right loans to transfer. Yet we are still concerned that deals may differ in unobserved quality in ways that might bias at least some of our findings. In particular, we are concerned that the special servicer might own deals with higher unobserved quality loans. Table 2 shows that the special servicer owns the B-piece in deals with a higher delinquency rate. Now we examine liquidation, conditional on delinquency. By conditioning on delinquency rather than special servicing, we remove the impact any actions taken by the special servicer in special servicing. If the exertion of the effort is the only reason for differences in the timing of liquidation, we would expect that the eventual liquidation of loans would be similar whether or not the special servicer owns the Bpiece.

The results, presented in Table 8, show that, conditional on delinquency, liquidation rates are higher, not lower, for deals in which the special servicer owns the B-piece. Thus, if anything, deals in which the special servicer owns the B-piece have worse unobserved quality. This suggests that the special servicer is especially accurate when referring loans to special servicing when she owns the B-piece. However, these findings are statistically different from zero in the first two columns based on whether a delinquent loan is liquidated in 6 months. In the last two columns, when we examine liquidation within one year, the coefficients drop in half and are not significantly different from zero. As above, these findings suggest that the special servicer handles additional delinquencies more quickly when she owns the B-piece. 


\section{E. Market prices of securities and agency conflicts (H4)}

Finally, we take advantage of initial bond pricing data from CMA to examine whether bond investors pay a premium for deals in which the special servicer owns the B-piece. The reasoning is straightforward: if there is value created from this incentive enhancing structure, the market should require lower yield in deals with this structure than in deals in which the special servicer does not own the B-piece, ceteris paribus. This finding would be especially striking given that deals in which the special servicer owns the B-piece have higher delinquency and liquidation rates.

In the regressions, we examine spreads within each bond rating class. Controlling for bond ratings provides for an alternative way of dealing with the issue of unobserved quality. After all, the ratings agency's primary role is to provide a more informed view about default probabilities. Discussions with the rating agencies confirm that while collateral quality and capital for special servicers are critical in determining bond ratings, they do not consider whether the special servicer owns the B-piece. In part, rating agencies do not know this information when they determine bond ratings, which must occur prior to the actual sale of the bonds. Also, ownership data on bonds is not available for all deals and there is often no guarantee that the special servicer will maintain ownership of the B-piece. Of course, selling the B-piece after a deal has gone public is likely quite difficult given the information asymmetry between the special servicer and any potential buyers of the first-loss position.

Hypothesis $\mathrm{H} 4$ predicts that investors should be willing to pay a premium for bonds in deals in which the special servicer owns the lowest rated tranche and that this premium should be most pronounced for the lowest rated tranches that face the greatest risk of losses. Regression results 
in Table 9 are consistent with this hypothesis. The dependent variable is the spread over the benchmark yield as reported in the CMA pricing data set (measured in basis points, or $0.01 \%$ ). In addition to whether the special servicer owns the most junior tranche, we include a complete set of dummy variables for each bond ratings category and year and quarter dummies. Since most of the deals are rated by more than one rating agency, we use the best rating from among all ratings. ${ }^{12}$ We also restrict the sample to bonds which have a fixed rate and thus are easier to evaluate. This cuts our sample of bonds by about 10 percent.

With all bonds (column 1), the coefficient on the special servicer owning the B-piece is negative and fairly small (about 8 basis points), and also not statistically different from zero at conventional confidence levels. However, these regressions include all rated tranches, while most of the benefits associated with the special servicer owning the B-piece go to the junior security holders who bear most of the credit risk. (Note: As of the date on this draft, there have never been any losses to CMBS securities with investment-grade ratings of BBB or above.)

In column 2, we examine only the tranches with non-investment-grade ratings (below BBB-). The sample drops appreciably to 78 observations. Most junior pieces are privately placed and are not publicly priced, so the regression sample mainly consists of senior tranches. For example, almost $97 \%$ of all tranches in our data have investment-grade ratings. Nonetheless, the coefficient on deals in which the special servicer owns the B-piece becomes much more negative and is highly statistically significant. In the bottom row of the table, we list the average spread for each regression sample. When all the tranches are included, the average effect of aligning the interests is fairly small, because the majority of tranches are senior securities that bear very little

\footnotetext{
${ }^{12}$ Previous versions of the paper also reported results that used the worst rating among all ratings assigned and results that included adjustable rate securities. Coefficient estimates and standard errors were similar, although they varied across specification. Results are available upon request.
} 
credit risk. When focusing only on the tranches with below investment-grade ratings in column 2, the estimated effects are much larger in magnitude. For the lowest rated tranches, the evidence suggests that the underwriter is able to sell securities at a spread that is $29 \%$ percent lower when the special servicer holds the B-piece.

These findings are consistent with underwriters facing a tradeoff in which they are able to sell securities at a lower yield when the special servicer owns the B-piece, but that the special servicer requires a premium to be willing to hold the B-piece.

\section{Conclusion}

The asset-backed securities market has exploded in recent years. Benefits of ABS include completing the market for securities, enhanced liquidity, transparency, and specialization. Nonetheless, this paper demonstrates that securitization also involves potentially serious moral hazard and agency conflicts associated with the separation of ownership and control of assets and conflicts of interest between junior and senior securities holders. These conflicts are similar to those faced by firms that finance with equity and debt, but are more pronounced given the large number of debt tranches in most ABS securitizations and the stricter priority claims that are enforced by courts in securitizations. Our findings suggest that securitization results in a secondbest solution in dealing with troubled loans relative to a situation in which there is a single entity that owns a whole loan and manages potential delinquencies and defaults. The special servicer, the agent in charge of the workout strategy for delinquent assets, may not always behave in the best interests of security holders. To curb the agency problem, the special servicer often holds the most junior tranche (the so-called B-piece). 
Using data on 357 CMBS deals involving over 46,000 loans, we find that the special servicer holds the B-piece in worse quality deals, with a greater percentage of realized delinquencies and liquidations after controlling for observable loan and deal attributes. Thus underwriters who have superior information appear to mitigate information asymmetries between investors and managers (special servicers) by aligning ownership and control in deals where this structure is most valuable. The special servicer appears to behave more efficiently in most situations when she owns the B-piece, transferring a smaller percentage of delinquent loans to costly special servicing and liquidating troubled loans more quickly. The market recognizes these benefits; spreads for non-investment grade bonds are 29 percent lower in deals in which the special servicer owns the B-piece. All of these findings are consistent with the predictions of agency theory.

However, the structure is not flawless. When deals face a larger percentage of delinquent loans, a special servicer who is also the B-piece holder reverses behavior by delaying liquidation, possibly because the downside loss can be shared with senior security holders. Together, these results show that securitization involves tradeoffs that may lead to a second-best outcome when handling troubled loans.

These findings still leave a large remaining unresolved puzzle: why doesn't the special servicer purchase the B-piece in all deals. After all, as the most informed party and the party in control of most decisions, the special servicer should have the highest willingness-to-pay. We provide two potential answers. First, the underwriter (and other investors) may be wary of the asset substitution problem. To the extent that special servicers delay liquidation when they suffer larger losses in a pool, the special servicer's high willingness-to-pay may be more than offset by expected losses in value for other tranches. Nonetheless, our bond pricing results suggest asset 
substitution is not a big concern, at least during a time when real estate markets have been strong and losses low.

A second potential explanation is that special servicers may be more risk averse than other investors, which may offset their potentially higher valuation for the B-piece. Special servicers in the CMBS market have unique skills that limit their ability to diversify into other areas. In addition, special servicers must hold capital and retain strong credit ratings in order to remain in business. Times when losses in existing CMBS securities are high may also correspond to times when profits from future deals may fall if credit if investors are wary of making new loans. Of special interest to this analysis, Figure 1 compares aggregate issuance to the percentage of deals in which the special servicer owns the B-piece. The percentage of deals in which the special servicer owns the B-piece in a given year (measured by either by dollars or number of deals) appears inversely related to the total issuance of CMBS securities. This observation is consistent with the view that special servicers face a tradeoff between their exposure to CMBS risk and the extent to which special servicers own the B-piece, although with eight years of aggregate data, this analysis is hardly definitive.

From a policy perspective, our finding that having the special servicer own the B-piece alleviates agency and moral hazard conflicts only when delinquency rates in a pool are relatively low is also a potential warning. Regulations for insurance companies and new risk-based capital requirements for banks allow institutions to hold less capital to protect against losses in securities than for losses in whole loans. Yet we still do not know how the ABS market would perform in a recession with appreciable declines in asset values. Our results surely do not generalize to such a situation. The recent growth in the private ABS market does not provide the data to address this question. Nonetheless, this is an issue that is worthy of additional attention as regulated 
institutions rely more heavily on rated ABS securities to fund future lending activities. 


\section{References}

Agrawal, Anup, and Gershon N. Mandelker (1987), “Managerial Incentives and Corporate Investment and Financing Decisions”. The Journal of Finance, Vol.42, No.4, 823-837.

Ambrose, Brett, Michael Lacour-Little, and Anthony Sanders (2006), “Does Regulatory Arbitrage of Asymmetric Information Drive Securitization?" Journal of Financial Services Research, forthcoming.

Ayotte, Ken and Stav Gaon (2005), “Asset-Backed Securities: Costs and Benefits of Bankruptcy Remoteness.” Columbia Business School mimeo, August 15.

Archer, Wayne R., Peter J. Elmer, David M. Harrison and David C. Ling (2002), “Determinants of Multifamily Mortgage Default”, Real Estate Economics 30(3), 445-473.

Brown, David T., Brian A. Ciochetti, and Timothy J. Riddiough (2004). “Theory and Evidence on the Resolution of Financial Distress,” University of Wisconsin mimeo, May.

Calomiris, Charles W. and Joseph R. Mason (2004), “Credit card securitization and regulatory arbitrage.” Journal of Financial Services Research, 26(1), 5-27.

Chen, Jun and Yongheng Deng (2003). “Commercial Mortgage Workout Strategy and Conditional Default Probability: Evidence from Special Serviced CMBS Loans”. USC Lusk Working Paper 2003-1008.

Ciochetti, Brian, Yongheng Deng, Gail Lee, James Shilling, and Rui Yao (2003), “A Proportional Hazards Model of Commercial Mortgage Default with Originator Bias.” Journal of Real Estate Finance and Economics, 27(1), 5-23.

Ciochetti, Brian A. and Timothy J. Riddiough (1998). “Timing, Loss Recovery and Economic Performance of Foreclosed Commercial Mortgages”. University of Wisconsin Working paper.

DeMarzo, Peter (2005). “The Pooling and Tranching of Securities: A Model of Informed Intermediation.” Review of Financial Studies, Vol. 18, No. 1, pp. 1-35.

Deng, Yongheng, John M. Quigley, and Anthony B. Sanders (2004), “Commercial Mortgage Terminations: Evidence from CMBS.” USC mimeo, December.

Downing, Christopher and Nancy E. Wallace (2005). “Commercial Mortgage Backed Securities: How Much Subordination is Enough?” University of California at Berkeley mimeo, January 4.

Eisenhardt, Kathleen M (1989). “Agency Theory: An Assessment and Review”. The Academy of Management Review, Vol.14,No.1, 57-74

Fama, Eugene F. (1980), “Agency Problems and the Theory of the Firm” The Journal of Political Economy, Vol.88, No.2, 288-307 
Fama, Eugene F. and Michael C. Jensen (1983), "Separation of Ownership and Control”. Journal of Law and Economics, Vol.26, No.2, 301-325.

Gaur, Vishal, Sridhar Seshadri, and Marti Subrahmanyam (2003). "Market Incompleteness and Super Value Additivity: Implications for Securitization,” Leonard N. Stern School of Business Working Paper, November.

Gorton, Gary B. and George G. Pennacchi (1995). "Banks and loan sales: Marketing nonmarketable assets.” Journal of Monetary Economics, Vol. 35, 389-411.

Han, Jun (1996). "To Securitize or Not To Securitize? The Future of Commercial Real Estate Debt Market”. Real Estate Finance (Summer):71-80.

Harris, Milton and Artur Raviv (1978), "Some Results on Incentive Contracts with Applications to Education and Employment, Health Insurance, and Law Enforcement”. The American Economic Review, Vol.68, No.1, 20-30

Jensen, Michael C. and Willian H. Meckling (1976), "Theory of the Firm: Managerial Behavior, Agency Costs and Ownership Structure”. Journal of Financial Economics 3, 305-360.

Laffont, Jean-Jacques and David Martimort (2002). The Theory of Incentives: The PrincipalAgent Model. Princeton University Press (Princeton).

Kopcke, Richard (1996), Risk and Capital of Insurance Companies.” New England Economic Review, July/August.

Murray, Michael, “Fitch Warns CMBS Servicers: Play Fair or Else”, MBA (10/2/2003)

Shavell Steven (1979), "Risk Sharing and Incentives in the Principal and Agent Relationship". The Bell Journal of Economics, Vol.10, No.1, 55-73

Singh, Harbir and Farid Harianto (1989), "Management-board Relationships, Takeover Risk and the Adoption of Golden Parathutes: An Empirical Investigation". Academy of Management Journal. Vol,32. No.1, 7-24.

Timothy J. Riddiough (1997). “Optimal Design and Governance of Asset-Backed Securities”. Journal of Financial Intermediation 6, 121-152

Timothy J. Riddiough (2000), "Forces Changing Real Estate for at Least a Little While: Market Structure and Growth prospects of the Conduit-CMBS Market", Real Estate Finance, 17, 52-61.

Vandell, Kerry D. (1984), “On the Assessment of Default Risk in Commercial Mortgage Lending”, AREUEA Journal 12, 270-296. 
Table 1 Summary of CMBS Deals by Closing Year

This table lists all the deals in the final sample by closing year. The third-fifth columns summarize the number and percentage of deals based on whether or not the special servicer (SPS) holds the B-piece.

\begin{tabular}{|c|c|c|c|c|c|c|c|}
\hline Year & $\begin{array}{c}\text { Number } \\
\text { of } \\
\text { Deals } \\
\end{array}$ & $\begin{array}{c}\text { SPS } \\
\text { Holds } \\
\text { B-piece } \\
\end{array}$ & $\begin{array}{c}\text { SPS Not } \\
\text { Hold } \\
\text { B-piece }\end{array}$ & $\begin{array}{c}\text { Pct in which } \\
\text { SPS Holds } \\
\text { B-piece } \\
\end{array}$ & $\begin{array}{c}\text { Total } \\
\text { Issuance } \\
\text { (\$million) } \\
\end{array}$ & $\begin{array}{l}\text { Avg Deal } \\
\text { Size } \\
\text { (\$million) } \\
\end{array}$ & $\begin{array}{c}\text { Avg \# } \\
\text { Loans } \\
\text { Per Deal }\end{array}$ \\
\hline 1993 & 1 & 1 & 0 & $100 \%$ & $\$ 21$ & $\$ 21$ & 197 \\
\hline 1994 & 4 & 2 & 2 & $50 \%$ & $\$ 1,110$ & $\$ 278$ & 90 \\
\hline 1995 & 18 & 8 & 10 & $44 \%$ & $\$ 5,260$ & $\$ 292$ & 80 \\
\hline 1996 & 25 & 20 & 5 & $80 \%$ & $\$ 11,100$ & $\$ 442$ & 140 \\
\hline 1997 & 31 & 24 & 7 & $77 \%$ & $\$ 24,700$ & $\$ 796$ & 145 \\
\hline 1998 & 43 & 27 & 16 & $63 \%$ & $\$ 50,100$ & $\$ 1,164$ & 210 \\
\hline 1999 & 43 & 21 & 22 & $49 \%$ & $\$ 39,800$ & $\$ 925$ & 232 \\
\hline 2000 & 53 & 33 & 20 & $62 \%$ & $\$ 41,600$ & $\$ 786$ & 130 \\
\hline 2001 & 47 & 25 & 22 & $53 \%$ & $\$ 39,600$ & $\$ 842$ & 124 \\
\hline 2002 & 44 & 32 & 12 & $73 \%$ & $\$ 37,700$ & $\$ 858$ & 105 \\
\hline 2003 & 48 & 28 & 20 & $58 \%$ & $\$ 51,300$ & $\$ 1,069$ & 106 \\
\hline Total & 357 & 221 & 136 & $62 \%$ & $\$ 302,291$ & $\$ 847$ & 144 \\
\hline
\end{tabular}


Table 2 Summary of Deals by each Special Servicer

This table summarizes deals by the name of each special servicer (SPS). Only special servicers with at least 5 deals are included. This table includes 89\% (92\%) of the number of deals (cutoff loan balance) in the final sample.

\begin{tabular}{|c|c|c|c|c|}
\hline $\begin{array}{l}\text { Special } \\
\text { Servicer }\end{array}$ & \# of Deals & $\begin{array}{c}\text { Total } \\
\text { Balance } \\
\text { (\$ millions) }\end{array}$ & $\begin{array}{c}\text { \# of Deals in } \\
\text { which SPS } \\
\text { Holds B-piece }\end{array}$ & $\begin{array}{l}\text { \# of Deals in } \\
\text { which SPS Not } \\
\text { Hold B-piece }\end{array}$ \\
\hline Lennar & 80 & $\$ 74,600$ & 64 & 16 \\
\hline GMAC & 67 & $\$ 53,600$ & 55 & 12 \\
\hline Midland & 33 & $\$ 27,800$ & 2 & 31 \\
\hline Orix & 25 & $\$ 22,800$ & 4 & 21 \\
\hline Criimi Mae & 24 & $\$ 23,700$ & 23 & 1 \\
\hline ARCap & 18 & $\$ 20,500$ & 16 & 2 \\
\hline Banc One & 14 & $\$ 13,200$ & 6 & 8 \\
\hline Lend Lease & 11 & $\$ 10,100$ & 7 & 4 \\
\hline Amresco & 10 & $\$ 9,430$ & 8 & 2 \\
\hline Clarion & 7 & $\$ 6,850$ & 6 & 1 \\
\hline J.E. Robert & 7 & $\$ 2,450$ & 5 & 2 \\
\hline GE Capital & 6 & $\$ 3,260$ & 5 & 1 \\
\hline First Union & 5 & $\$ 5,370$ & 1 & 4 \\
\hline Gespa & 5 & $\$ 1,740$ & 0 & 5 \\
\hline Wells Fargo & 5 & $\$ 3,590$ & 1 & 4 \\
\hline Total & 317 & $\$ 278,990$ & 203 & 114 \\
\hline
\end{tabular}


Table 3 Comparison of Deals Based on Whether the Special Servicer Holds the B-piece

This table compares some basic characteristics of deals in which the special servicer (SPS) holds the B-piece or does not hold the B-piece. The fourth column presents t-statistics for the test of whether the means of each variable are equal in columns 2 and 3 . All delinquency measures are the percentage of outstanding balance of delinquent loans over outstanding balance of all loans in a deal.

\begin{tabular}{|c|c|c|c|}
\hline & $\begin{array}{c}\text { Deals in which SPS } \\
\text { Does Not } \\
\text { Hold B-piece }\end{array}$ & $\begin{array}{c}\text { Deals in which } \\
\text { SPS Holds } \\
\text { B-piece }\end{array}$ & $\begin{array}{l}\text { T-stat for } \\
\text { difference }\end{array}$ \\
\hline Balance (\$mil) & $\$ 819$ & $\$ 864$ & -0.84 \\
\hline Number of Loans & 128 & 154 & -1.38 \\
\hline Loan-to-Value Percent & $67.1 \%$ & $66.4 \%$ & -1.01 \\
\hline $\begin{array}{l}\text { Debt Service Coverage } \\
\text { Ratio }\end{array}$ & 1.59 & 1.57 & 0.28 \\
\hline $\begin{array}{l}\text { Weighted Average } \\
\text { Coupon yield }\end{array}$ & $7.58 \%$ & $7.72 \%$ & 1.02 \\
\hline $\begin{array}{l}\text { AAA Subordination } \\
\text { Level }\end{array}$ & $23.4 \%$ & $22.2 \%$ & 1.33 \\
\hline $\begin{array}{l}\text { Pct. of Loans more than } \\
30 \text { days delinquent }\end{array}$ & $0.25 \%$ & $0.34 \%$ & -1.02 \\
\hline $\begin{array}{l}\text { Pct. of Loans more than } \\
60 \text { days delinquent }\end{array}$ & $0.09 \%$ & $0.19 \%$ & -1.90 \\
\hline $\begin{array}{l}\text { Pct. of Loans more than } \\
90 \text { days delinquent }\end{array}$ & 0.39\% & $0.74 \%$ & -1.95 \\
\hline $\begin{array}{l}\text { Pct. of Loans with any } \\
\text { delinquency }\end{array}$ & $0.73 \%$ & $1.95 \%$ & -2.21 \\
\hline
\end{tabular}




\section{Table 4 Delinquency Regressions}

This table presents the results from regressing the delinquency rate in year $t$ on explanatory variables in the previous year (t-1). Estimates control for correlation across years within each deal and heteroskedasity.

Dependent variable: Percentage of Loan Balance in a Deal that is Delinquent

\begin{tabular}{lcccccc}
\hline & $\mathbf{( 1 )}$ & $\mathbf{( 2 )}$ & $\mathbf{( 3 )}$ & $\mathbf{( 4 )}$ & $\mathbf{( 5 )}$ & $\mathbf{( 6 )}$ \\
\hline SPS owns B-piece & 0.92 & 0.94 & 0.81 & 0.82 & 1.09 & 1.02 \\
& {$[2.86]^{* *}$} & {$[2.90]^{* *}$} & {$[2.40]^{* *}$} & {$[2.52]^{* *}$} & {$[2.07]^{* *}$} & {$[2.13]^{* *}$} \\
Loan-to-Value & -0.035 & & -0.047 & & -0.044 & \\
& {$[0.53]$} & & {$[0.60]$} & & {$[0.61]$} & \\
DSCR & -1.77 & & -2.44 & & -1.67 & \\
& {$[1.66]^{*}$} & & {$[1.75]^{*}$} & & {$[1.32]$} & \\
LTV is 0.60 to 0.80 & & -0.34 & & 0.25 & & -0.03 \\
& & {$[0.25]$} & & {$[0.16]$} & & {$[0.02]$} \\
LTV > 0.80 & & -1.12 & & -2.33 & & -1.77 \\
& & {$[0.75]$} & & {$[1.16]$} & & {$[1.00]$} \\
DSCR <1.2 & & 1.50 & & 0.66 & & -1.00 \\
& & {$[0.92]$} & & {$[0.47]$} & & {$[0.64]$} \\
DSCR is 1.2 to 1.6 & & 0.49 & & 0.73 & & 0.52 \\
& & {$[1.22]$} & & {$[1.58]$} & & {$[0.98]$} \\
Pct fixed rate loans & & & -0.016 & -0.017 & -0.004 & -0.004 \\
& & & {$[1.30]$} & {$[1.62]$} & {$[0.26]$} & {$[0.26]$} \\
Constant & 6.06 & 0.96 & 10.27 & 3.05 & 8.34 & 2.64 \\
& {$[1.06]$} & {$[0.89]$} & {$[1.39]$} & {$[2.10]^{* *}$} & {$[1.36]$} & {$[1.74]^{*}$} \\
Prop Type Controls & & & $Y$ & $Y$ & $Y$ & Y \\
Year Dummy Vars & & & Y & Y & Y & Y \\
SPS Dummy Vars & & & & & Y & Y \\
Observations & 895 & 895 & 895 & 895 & 895 & 895 \\
R-squared & 0.02 & 0.01 & 0.11 & 0.1 & 0.15 & 0.15 \\
\hline
\end{tabular}


Table 5 Transfer to Special Servicing Conditional on Delinquency

The dependent variable is a dummy variable that equals 1 if a delinquent loan was transferred to special servicing in a given number of months and 0 otherwise. The table reports partial effects. Estimates control for correlation across years within each deal and heteroskedasity.

\begin{tabular}{lccccc}
\hline & \multicolumn{5}{c}{ Transfer to Special Servicing within: } \\
& 2 Months & 3 Months & 4 Months & 5 Months & 6 Months \\
\hline SPS owns B-piece & -0.092 & -0.075 & -0.131 & -0.125 & -0.138 \\
& {$[2.43]^{* *}$} & {$[1.62]$} & {$[2.53]^{* *}$} & {$[2.43]^{* *}$} & {$[2.60]^{* *}$} \\
LTV is .60 to .80 & 0.02 & 0.01 & 0.036 & 0.036 & 0.048 \\
& {$[0.64]$} & {$[0.28]$} & {$[0.88]$} & {$[0.89]$} & {$[1.16]$} \\
LTV > 80 & -0.043 & -0.107 & -0.156 & -0.155 & -0.158 \\
& {$[1.12]$} & {$[2.35]^{* *}$} & {$[3.15]^{* *}$} & {$[3.11]^{* *}$} & {$[3.12]^{* *}$} \\
DSCR <1.2 & 0.06 & 0.06 & 0.12 & 0.11 & 0.12 \\
DSCR is 1.2 to 1.6 & {$[1.82]^{*}$} & {$[1.59]$} & {$[2.90]^{* *}$} & {$[2.76]^{* *}$} & {$[2.81]^{* *}$} \\
& -0.003 & -0.012 & 0.005 & 0.004 & 0.004 \\
Deal Type Dummy & {$[0.11]$} & {$[0.34]$} & {$[0.13]$} & {$[0.11]$} & {$[0.10]$} \\
Property Type Dummy & $\mathrm{Y}$ & $\mathrm{Y}$ & $\mathrm{Y}$ & $\mathrm{Y}$ & $\mathrm{Y}$ \\
Year Dummy & $\mathrm{Y}$ & $\mathrm{Y}$ & $\mathrm{Y}$ & $\mathrm{Y}$ & $\mathrm{Y}$ \\
SPS Dummy & $\mathrm{Y}$ & $\mathrm{Y}$ & $\mathrm{Y}$ & $\mathrm{Y}$ & $\mathrm{Y}$ \\
Observations & $\mathrm{Y}$ & $\mathrm{Y}$ & $\mathrm{Y}$ & $\mathrm{Y}$ & $\mathrm{Y}$ \\
Pseudo-R square & 1,327 & 1,329 & 1,342 & 1,342 & 1,342 \\
& 0.056 & 0.059 & 0.067 & 0.067 & 0.075
\end{tabular}




\section{Table 6 Liquidation Conditional on Special Servicing}

Estimates control for correlation across loans within each deal and heteroskedasticity. The table reports partial effects.

Dependent variable: Dummy that equals to 1 if a loan was liquidated (default) in 6 months (or 1 year) after transfer to special servicing and 0 otherwise

\begin{tabular}{lcccccc}
\hline & \multicolumn{3}{c}{$\begin{array}{c}\text { Liquidated } \\
\text { in 6 Months }\end{array}$} & \multicolumn{3}{c}{$\begin{array}{c}\text { Liquidated } \\
\text { in 1 Year }\end{array}$} \\
\hline SPS owns B-piece & 0.03 & 0.031 & 0.032 & 0.051 & 0.052 & 0.059 \\
& {$[2.54]^{* *}$} & {$[2.65]^{* *}$} & {$[1.70]^{*}$} & {$[2.66]^{* *}$} & {$[2.71]^{* * *}$} & {$[1.84]^{*}$} \\
Loan-to-Value & 0.002 & & & 0.003 & & \\
& {$[7.08]^{* *}$} & & & {$[6.46]^{* *}$} & & \\
DSCR & -0.004 & & & -0.03 & & \\
& {$[0.35]$} & & & {$[1.99]^{* *}$} & & -0.026 \\
LTV is .60 to .80 & & -0.015 & -0.017 & & -0.025 \\
& & {$[0.79]$} & {$[0.88]$} & & {$[0.96]$} & {$[0.86]$} \\
LTV > 80 & & 0.139 & 0.139 & & 0.197 & 0.198 \\
& & {$[4.67]^{* *}$} & {$[4.59]^{* *}$} & & {$[5.05]^{* *}$} & {$[4.83]^{* *}$} \\
DSCR < 1.2 & & 0.013 & 0.017 & & 0.068 & 0.068 \\
& & {$[0.73]$} & {$[0.94]$} & & {$[2.43]^{* *}$} & {$[2.35]^{* *}$} \\
DSCR is 1.2 to 1.6 & & 0.003 & 0.003 & & 0.061 & 0.046 \\
& & {$[0.15]$} & {$[0.17]$} & & {$[2.28]^{* *}$} & {$[1.66]^{*}$} \\
Deal Type Dummy & $\mathrm{Y}$ & $\mathrm{Y}$ & $\mathrm{Y}$ & $\mathrm{Y}$ & $\mathrm{Y}$ & $\mathrm{Y}$ \\
Property Type & & & & & & \\
Dummy & $\mathrm{Y}$ & $\mathrm{Y}$ & $\mathrm{Y}$ & $\mathrm{Y}$ & $\mathrm{Y}$ & $\mathrm{Y}$ \\
Year Dummy & $\mathrm{Y}$ & $\mathrm{Y}$ & $\mathrm{Y}$ & $\mathrm{Y}$ & $\mathrm{Y}$ & $\mathrm{Y}$ \\
SPS Dummy & & & $\mathrm{Y}$ & & & $\mathrm{Y}$ \\
Observations & 1,532 & 1,532 & 1,372 & 1,532 & 1,532 & 1,372 \\
Pseudo-R square & 0.111 & 0.122 & 0.142 & 0.088 & 0.094 & 0.121 \\
\hline
\end{tabular}


Table 7 Liquidation Conditional on Special Servicing for Serious Delinquent Deals

Serious delinquency equals 1 if there are more than $\mathrm{X} \%$ of the deal in delinquency and 0 otherwise. The regressions also include an interaction term of SPS owns B-piece and deal is seriously delinquent. Estimates control for correlation across loans within each deal and heteroskedasity. The table reports partial effects.

Dependent variable: Dummy that equals to 1 if a loan was liquidated in the 6 months after transfer to special servicing and 0 otherwise.

\section{Level of Serious Delinquency (pct of deal that is delinquent)}

\begin{tabular}{lccccc} 
& $\mathbf{2 \%}$ & $\mathbf{3} \%$ & $\mathbf{3} \%$ & $>\mathbf{5 \%}$ & $>\mathbf{6 \%}$ \\
\hline SPS owns B-piece & 0.036 & 0.040 & 0.042 & 0.040 & 0.041 \\
& {$[1.85]^{*}$} & {$[2.16]^{* *}$} & {$[2.25]^{* *}$} & {$[2.17]^{* *}$} & {$[2.17]^{* *}$} \\
(SPS owns B-piece)* & & & & & \\
(Deal is seriously Dlq) & -0.050 & -0.068 & -0.068 & -0.064 & -0.063 \\
& {$[2.02]^{* *}$} & {$[2.56]^{* *}$} & {$[2.75]^{* *}$} & {$[2.90]^{* *}$} & {$[2.45]^{* *}$} \\
Deal is Seriously & & & & & \\
Delinquent & 0.083 & 0.124 & 0.129 & 0.173 & 0.222 \\
& {$[2.97]^{* *}$} & {$[2.55]^{* *}$} & {$[2.57]^{* *}$} & {$[3.10]^{* *}$} & {$[2.52]^{* *}$} \\
LTV is .60 to .80 & -0.016 & -0.014 & -0.014 & -0.014 & -0.016 \\
& {$[0.89]$} & {$[0.77]$} & {$[0.77]$} & {$[0.77]$} & {$[0.85]$} \\
LTV > .80 & 0.138 & 0.140 & 0.139 & 0.139 & 0.142 \\
& {$[4.74]^{* *}$} & {$[4.71]^{* *}$} & {$[4.71]^{* *}$} & {$[4.69]^{* *}$} & {$[4.69]^{* *}$} \\
DSCR $<1.2$ & 0.014 & 0.016 & 0.016 & 0.017 & 0.014 \\
& {$[0.84]$} & {$[0.93]$} & {$[0.92]$} & {$[0.97]$} & {$[0.80]$} \\
DSCR is 1.2 to 1.6 & 0.002 & 0.002 & 0.002 & 0.002 & 0.000 \\
& {$[0.13]$} & {$[0.14]$} & {$[0.12]$} & {$[0.14]$} & {$[0.02]$} \\
Deal Type Dummy & $\mathrm{Y}$ & $\mathrm{Y}$ & $\mathrm{Y}$ & $\mathrm{Y}$ & $\mathrm{Y}$ \\
Property Type Dummy & $\mathrm{Y}$ & $\mathrm{Y}$ & $\mathrm{Y}$ & $\mathrm{Y}$ & $\mathrm{Y}$ \\
Year Dummy & $\mathrm{Y}$ & $\mathrm{Y}$ & $\mathrm{Y}$ & $\mathrm{Y}$ & $\mathrm{Y}$ \\
SPS Dummy & $\mathrm{Y}$ & $\mathrm{Y}$ & $\mathrm{Y}$ & $\mathrm{Y}$ & $\mathrm{Y}$ \\
Observations & 1,372 & 1,372 & 1,372 & 1,372 & 1,372 \\
Pseudo-R square & 0.1521 & 0.1504 & 0.1511 & 0.1529 & 0.1479 \\
& & & &
\end{tabular}




\section{Table 8 Liquidation Conditional on Delinquency}

Estimates control for correlation across loans within each deal and heteroskedasity. The table reports partial effects.

Dependent variable: Dummy that equals to 1 if a loan was liquidated in 6 months (or 1 year) after the date on which the loan was recorded as in delinquency and 0 otherwise.

\begin{tabular}{|c|c|c|c|c|}
\hline \multirow[b]{2}{*}{ SPS owns B-piece } & \multicolumn{2}{|c|}{ Liquidate in 6 Months } & \multicolumn{2}{|c|}{ Liquidate in 1 Year } \\
\hline & 0.53 & 0.54 & 0.26 & 0.27 \\
\hline & {$[2.37]^{* *}$} & {$[2.36]^{* *}$} & {$[1.28]$} & {$[1.32]$} \\
\hline \multirow[t]{2}{*}{ Loan-to-Value } & 0.01 & & 0.006 & \\
\hline & {$[3.42] * *$} & & {$[1.95]^{*}$} & \\
\hline \multirow[t]{2}{*}{ DSCR } & 0.033 & & -0.035 & \\
\hline & {$[0.37]$} & & {$[0.41]$} & \\
\hline \multirow[t]{2}{*}{ LTV is .60 to .80} & & -0.034 & & -0.136 \\
\hline & & {$[0.20]$} & & {$[0.95]$} \\
\hline \multirow[t]{2}{*}{$\mathrm{LTV}>.80$} & & 0.53 & & 0.24 \\
\hline & & {$[2.73]^{* *}$} & & [1.39] \\
\hline \multirow[t]{2}{*}{ DSCR $<1.2$} & & -0.029 & & 0.08 \\
\hline & & {$[0.16]$} & & {$[0.49]$} \\
\hline \multirow[t]{2}{*}{ DSCR is 1.2 to 1.6} & & 0.00 & & 0.13 \\
\hline & & {$[0.00]$} & & {$[0.84]$} \\
\hline \multirow[t]{2}{*}{ Constant } & -2.26 & -1.75 & -1.85 & -1.44 \\
\hline & {$[2.77]^{* *}$} & {$[2.17]^{* *}$} & {$[2.28]^{* *}$} & {$[1.82]^{*}$} \\
\hline Property Type Dummy & $\mathrm{Y}$ & $\mathrm{Y}$ & $\mathrm{Y}$ & $\mathrm{Y}$ \\
\hline Year Dummy & $\mathrm{Y}$ & $\mathrm{Y}$ & $\mathrm{Y}$ & $\mathrm{Y}$ \\
\hline SPS Dummy & $\mathrm{Y}$ & $\mathrm{Y}$ & $\mathrm{Y}$ & $\mathrm{Y}$ \\
\hline Observations & 1,301 & 1,301 & 1,332 & 1,332 \\
\hline Pseudo-R square & 0.1453 & 0.1523 & 0.1749 & 0.1788 \\
\hline
\end{tabular}


Table 9 Initial Bond Pricing Regression

Dependent variable: The spread over benchmark (basis points, or .01\%)

\begin{tabular}{|c|c|c|}
\hline & All bonds & Bonds rated BB or less \\
\hline & (1) & (2) \\
\hline \multirow[t]{2}{*}{ SPS owns B-piece } & -8.2 & -136.7 \\
\hline & [1.28] & {$[3.46]^{* *}$} \\
\hline \multirow[t]{2}{*}{$\mathrm{AA}+$} & 17.5 & \\
\hline & {$[3.64]^{* *}$} & \\
\hline \multirow[t]{2}{*}{ AA } & 18.5 & \\
\hline & {$[12.32]^{* *}$} & \\
\hline \multirow[t]{2}{*}{ AA- } & 22.2 & \\
\hline & {$[10.36]^{* *}$} & \\
\hline \multirow[t]{2}{*}{$\mathrm{A}+$} & 25.5 & \\
\hline & {$[7.22]^{* *}$} & \\
\hline \multirow[t]{2}{*}{ A } & 37.9 & \\
\hline & {$[20.98]^{* *}$} & \\
\hline \multirow[t]{2}{*}{ A- } & 41.5 & \\
\hline & {$[18.26]^{* *}$} & \\
\hline \multirow[t]{2}{*}{$\mathrm{BBB}+$} & 74.5 & \\
\hline & {$[25.51]^{* *}$} & \\
\hline \multirow[t]{2}{*}{ BBB } & 95.4 & \\
\hline & {$[30.37]^{* *}$} & \\
\hline \multirow[t]{2}{*}{ BBB- } & 144 & \\
\hline & {$[35.83]^{* *}$} & \\
\hline \multirow[t]{2}{*}{$\mathrm{BB}^{+}$} & 263 & \\
\hline & {$[8.49]^{* *}$} & \\
\hline \multirow[t]{2}{*}{$\mathrm{BB}$} & 263 & 49.3 \\
\hline & {$[12.68]^{* *}$} & {$[3.05]^{* *}$} \\
\hline \multirow[t]{2}{*}{ BB- } & 280 & 111 \\
\hline & {$[7.04]^{* *}$} & {$[5.25]^{* *}$} \\
\hline \multirow[t]{2}{*}{$\mathrm{B}^{+}$} & 525 & 261 \\
\hline & {$[5.88]^{* *}$} & {$[6.00]^{* *}$} \\
\hline \multirow[t]{2}{*}{ B } & 550 & 295 \\
\hline & {$[15.94]^{* *}$} & {$[12.88]^{* *}$} \\
\hline \multirow[t]{2}{*}{ B- } & 741 & 503 \\
\hline & {$[12.79]^{* *}$} & {$[22.96]^{* *}$} \\
\hline \multirow[t]{2}{*}{ CCC } & 1,758 & 1,418 \\
\hline & {$[31.87]^{* *}$} & {$[22.62] * *$} \\
\hline \multirow[t]{2}{*}{ Constant } & 132 & 667 \\
\hline & {$[8.19]^{* *}$} & {$[9.79]^{* *}$} \\
\hline Observations & 2,271 & 78 \\
\hline R-squared & 0.85 & 0.99 \\
\hline Average Spread & 123.1 & 474.3 \\
\hline
\end{tabular}

Estimates control for correlation across tranches in each deal and heteroskedasity. Regressions contain year and quarter dummies. Sample includes only fixed-rate bonds. 
Figure 1: Total Issuance Vs. Percentage of Deals in Which SPS Holds the B-piece
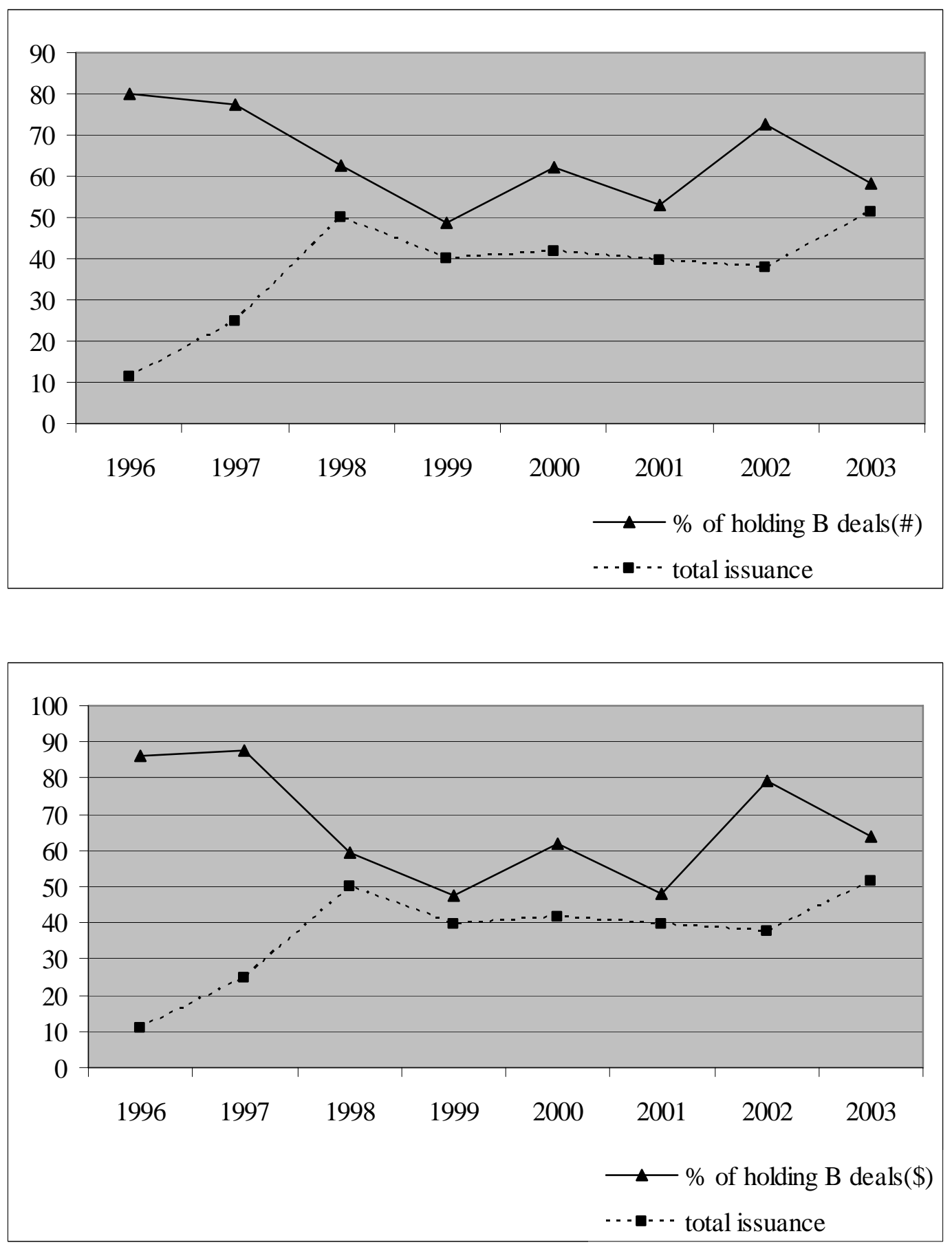

Notes:

The top (bottom) figure shows the total issuance versus the percentage of deals in which the SPS holds the B-piece measured by number of deals (issue size in U.S. \$) in our final sample. Total issuance is in million U.S. dollars. 